\title{
Skull trauma in Egyptian and Hippocratic Medicine
}

Plinio Prioreschi

\section{SUMMARY}

To compare the treatment of skull trauma in Egyptian and Hippocratic medicine, the author reviews the pertinent passages of the Smith Papyrus and of the Hippocratic Corpus. By examining the treatment of similar cases reported in the two documents, it is concluded that the Egyptian physician, with his more conservative approach, pursued a more effective and less dangerous course of action than the Hippocratic physician, who would aggressively intervene with trephination and scraping of the bone.

It is commonly accepted that with the Hippocratic paradigm medicine became naturalistic and left behind the farrago of magic and religious practices that had kept previous medical systems in the hands of the priest and the sorcerer. It is also commonly accepted that Hippocratic medicine, being more rational, was more effective in dealing with disease. However, paradigmatic changes in medical thinking are, as a rule, not sudden and complete and, in fact, supernatural elements can be found in Hippocratic medicine ${ }^{1}$. Moreover, Hippocratic medicine was not always more effective than previous medicines, especially than Egyptian medicine, which often relied on empirical elements and, in fact, significantly influenced Greek medicine ${ }^{2}$.

It is difficult to compare one ancient medical system with another in terms of effectiveness except in particular cases. An occasion for such a comparison of Egyptian and Greek medicine is offered by the treatment of head trauma in the Hippocratic Corpus and in the Smith Papyrus. The purpose of this paper is to underline that, in this particular field, Egyptian medicine was, in fact, more effective and less dangerous than Hippocratic medicine.

The Smith Papyrus, written around 1650 B. C., is a copy of a text which could go back to the Old Kingdom (2700-2200 B.C.), possibly even to the early part of that age ${ }^{3}$, in other words, to perhaps two thousand years before the Corpus Hippocraticum was composed; the document was published 
in 1930 by James H. Breasted ${ }^{4}$. That part of it called The Surgical Treatise ${ }^{5}$ discusses forty-eight cases, most of them injuries; it begins with the head and skull and, proceeding a capite ad calcem, continues with the nose, face and ears, neck, clavicle, humerus, thorax, shoulders, and spinal column, where the text stops abruptly. Cases 1-17 (the first incomplete) concern lesions of the head and face. The general approach to disease is objective, and neither supernatural forces nor incantations are invoked to achieve the therapeutic goal (case 9 is the only exception to this rule). The text is in a form that suggests a teacher instructing a pupil, and each case is discussed systematically in the following order:

1. title

2. examination

3. diagnosis

4. treatment (except in cases which are considered untreatable)

5. glosses

The Title consists of the word "Instructions" followed by the identification of the lesion. The Examination consists in the description of the injury, the symptoms, and the manœuvres (e.g., palpation) to reach the diagnosis. The Diagnosis is always introduced by the words: "Thou shouldst say concerning him [that is, the patient]" followed by the diagnosis proper (e.g., "one having a gaping wound in the head") and concludes with one of three alternatives concerning the possibility of treatment:

1. "An ailment which I will treat"

2. "An ailment with which I will contend"

3. "An ailment not to be treated"

In this early example of triage, the simpler cases are in the first category, in the second the serious ones, and in the third the cases that the surgeon considers hopeless. The Treatment may be exclusively surgical (e.g., bandages, application of adhesive plaster to bring together the margins of a gaping wound, cauterization, splints and braces), surgical and medical, or exclusively medical (e.g., local application of fresh meat, honey, and various mineral and vegetable drugs). Sometimes instructions concerning treatment are given under the heading "Diagnosis". The Glosses, in the number of sixty-nine, were written a few centuries after the original text to clarify 
various points and also to explain terms that were already so old that they required interpretation by the end of the Old Kingdom. For example, in nine cases, we find the expression "Put him (the patient) at his mooring stakes." The glosses explain that the expression means: "putting him on his customary diet, without administering to him a prescription."

We shall select from the Smith Papyrus cases of skull trauma ${ }^{6}$ which have their counterpart in the Hippocratic Corpus, and we shall compare the treatments in terms of effectiveness and safety.

\section{Head wound with no fracture of the skull (Case 2)}

Title: Instruction concerning a [gaping] wound [in his head], penetrating to the bone.

Examination: If thou examinest a man having a [gaping] wound [in] his [head], penetrating to the bone, thou shouldst lay thy hand upon it (and) [thou shouldst] pal[pate hi]s [wound]. If thou findest his skull [uninjured not hav]ing a perforation in it, (conclusion in diagnosis).

Diagnosis: Thou shouldst say regarding [him]: "One hav[ing a gaping wou]nd in his head. An ailment which I will treat."

Treatment: [Thou] shouldst bind [fresh meat upon it the first day; thou shouldst apply for him two strips of linen, and treat afterward with grease, honey, (and) lin]t every day until he recovers.

Glosses. Gloss B : As for: "Two strips of linen", [it means] two bands [of linen which one applies upon the two lips of the gaping wound in order to cause that one join] to the other ${ }^{7}$.

\section{Head wound with undisplaced fracture of the skull (Case 3)}

Title: [Instructions concerning] a gaping [wo] und in his head penetrating to the bone (and) perforating his [skull].

Examination: [If thou examinest a man having a gaping wound in] his [head], penetrating the bone, (and) perforating his skull; thou should palpate the wound; [shouldst thou find him unable to look at his two shoulders] and his [br] east, (and) suffering with stiffness in his neck, (conclusion in diagnosis). 
Diagnosis: Thou shouldst say [regarding] him: "One having [a gaping wound in his head, penetrating to the bone, (and) per]forating his skull, while he suffers with stiffness in his neck. An ailment which I will treat."

Treatment: Now [after thou hast stitched it ${ }^{8}$, thou shouldst lay] fresh [meat] upon his wound the first day. Thou shouldst not bind him. Moor (him) [at his mooring stakes until the period of his injury passes by]. Thou shouldst [tre] at it afterward with grease, honey, and lint every day, until he recovers.

Glosses. Gloss A: [As for : "Perforating his skull," it means]... his skull, a contracted smash, through his incurring a break like a puncture of a (pottery) jar, ... which he incurred." Gloss D: As for: "Moor (him) at his mooring stakes," it means putting him on his customary diet, without administering to him a prescription. ${ }^{9}$

\section{Head wound with comminuted fracture of the skull (Case 5)}

Title: Instructions concerning a gaping wound in his head, smashing his skull.

Examination: If thou examinest a man having a gaping wound in his head, penetrating to the bone, (and) smashing his skull; thou shouldst palpate his wound. Shouldst thou find that smash which is in his skull deep (and) sunken under thy fingers, while the swelling which is over it protrudes, he discharges blood from both his nostrils (and) both his ears, (and) he suffers with stiffness of his neck, so that he is unable to look at his two shoulders and his breast, (conclusion in diagnosis).

Diagnosis: Thou shouldst say regarding him: "One having a gaping wound in his head, penetrating to the bone, (and) smashing his skull, while he suffers with stiffness in his neck. An ailment not to be treated."

Treatment: Thou shall not bind him, (but) moor (him) at his mooring stakes, until the period of his injury passes by.

Glosses. Gloss A: As for: "Smashing his skull," it means a smash of his skull (such that) bones, getting into that smash, sink into the interior of his skull. The "Treatise on What Pertains to His Wounds" ${ }^{10}$ states: "It means a smash of his skull into numerous fragments, which sink into the interior of his skull."

The following are cases from the Hippocratic Corpus which are similar to those of the Smith Papyrus mentioned above: 


\section{Head wound with no fracture of the skull}

When, therefore, you incise a head wound ${ }^{11} \ldots$ and you want to know whether ... [the bone] has or has not suffered any injury from the weapon, the size of the open wound should be such as seems fully sufficient. When operating you should detach the scalp from the skull... then plug the whole wound with lint, so that the next day it will present the widest possible lesion of continuity with least pain. Next day, when you take out the lint, if, on looking to see what the bone has suffered, the nature of the lesion is not clear, and you cannot even see whether the skull has anything wrong with it, yet the weapon seems to have reached and damaged the bone, you should scrape down into it with a raspatory, both up and down... and again transversely so as to get a view of latent fractures and contusion... for rasping shows up the mischief well, even if these lesions though existing in the bone are not otherwise manifest. And if you see a weapon hedra ${ }^{12}$ in the bone, you should scrape the hedra itself and the bone containing it, in case, as often happens, fissure with contusion or contusion alone accompanies the hedra, and not being well marked, is overlooked. ${ }^{13}$

Scraping such superficial lesions of the bone was, of course, not only useless and painful, but very dangerous as well because of the possibility of osteomyelitis and infection of the surrounding tissues. In spite of this, if the physician did not find any hedra, he would persist:

Should you suspect the skull to be fractured or contused or both... if you cannot otherwise distinguish by inspection whether the skull is fractured or contused... then you must drop on the bone the very black solution ${ }^{14}$, anoint the wound with the dissolved black drug, putting linen on it and moisten with oil, and then apply barley-meal plaster and bandage. Next day, having opened and cleansed the wound, scrape further, and... the bone will be white after scraping, but the fracture and contusion will have absorbed the dissolved drug [the black solution] and will be black in the white bone. You should again scrape down into this fracture which shows black, and if on further scraping you clear it away and make it invisible, there has been more or less contusion of the bone, which also produced the fracture now abolished by the raspatory, but... [there is now] less danger... [because] now the fracture has disappeared. Should it go deep and refuse to disappear when scraped, such an accident is a case for trephining ${ }^{15}$.

\section{Head wound with undisplaced fracture of the skull}

In case the unfortunate patient had a non-displaced fracture, trephining would follow. The instrument, as described by Celsus, was rotated by a bow and strap ${ }^{16}$ and was similar to those used for starting fire, as in Egypt ${ }^{17}$.

As to trephining, when it is necessary to trephine a patient, keep the following in mind... you should not, in trephining, remove the bone at once down to the membrane [the dura mater], for it is not good for the membrane to be denuded of bone and exposed to morbid influences for a long time, or it may end by becoming macerated. There is also another 
danger that, if you immediately remove the bone by trephining down to the membrane, you may, in operating, wound the membrane with the trephine. You should rather stop the operation when there is very little left to be sawn through, and the bone is movable; and allow it to separate of its own accord ${ }^{18}$.

Obviously the physician was aware of the danger of piercing the dura mater (a mortal meningitis would surely follow) and subsequently, as Celsus tells us, a plate called "meningophilax" (guardian of the membrane) was used to protect it ${ }^{19}$. If the surgeon was skilled enough that the dura mater was not pierced, the patient had a chance to survive the ordeal although other complications, like osteomyelitis and infection of the surrounding tissues must have been frequent ${ }^{20}$.

\section{Head wound with displaced fracture of the skull}

Only in cases of displaced and comminuted fractures of the skull does the Hippocratic physician act with restraint.

Cases of contused fracture of the bones [of the skull] with depression when they are broken up and even comminuted very widely, are less dangerous (than other injuries) if the covering of the brain is unharmed, and where the bones are broken in with many and rather wide fractures they are still less dangerous, and are more readily removed. In such cases you should do no trephining, nor run risk in trying to remove bone fragments before they come up of their own accord ${ }^{21}$.

The notion that displaced and comminuted fractures of the skull are less dangerous than simple undisplaced ones is to be noted. The same concept is repeated in On Places in Man ("if the bone is shattered, there is no danger") as quoted below.

The most striking difference between the Egyptian and Hippocratic treatments of head injuries concerns cases with no fracture or with undisplaced fracture of the skull. The Egyptian physician, as we have seen, follows a very conservative treatment which consists in drawing near the two margins of the wound with adhesive plaster and application of fresh meat, held in place by a bandage, followed by grease and honey "until... [the patient] recovers."

The Hippocratic physician, on the other hand, with a furor secandi that appears absurd to the modern reader, enlarges the wound and scrapes the bone in search of a hedra. If no hedra is found, he persists with scraping, after putting into the wound the "black solution", in search of a possible undisplaced fracture that had escaped detection. 
Why did the Hippocratic physician scrape and trephine the skull in cases of undisplaced fracture? In spite of the fact that by the time of Celsus (first century A.D.) the practitioner was already much more cautious ${ }^{22}$, the Hippocratic physician was very peremptory:

When, after recognizing that the skull is injured, either broken or contused, or injured in some way, one makes a mistake and neither scrapes nor trephines as though it were not required, yet the bone is not sound, fever as a rule will seize the patient within fourteen days in winter, and in summer just after seven days. When this occurs, the lesion gets a bad color and little ichor flows from it, the inflammation dies completely out of it... necrosis of the bone then sets in... and the patient dies delirious ${ }^{23}$.

Whereas scraping was obviously futile in all cases, trephining could, in theory, relieve an epidural hemorrhage secondary to the fracture. It is evident, however, that this could not be the reason for the latter procedure, as the Hippocratic physician had no way to diagnose it and did not recognize it as a nosological entity. It has been pointed out ${ }^{24}$ that theoretical considerations about accumulation of humors after head trauma may have been the reason. Although such considerations may have played a role, the explanation is to be found in On Places in Man:

Fracture of the skull: if the bone is shattered, there is no danger; one will treat this with moistening medication. If the bone is only cracked, there is great danger. In this case it is necessary to trephine so that the ichor, trickling from the cracked bone, will not infect the meningeal membrane. The ichor, in fact, can cause pain and delirium because, the fissure being very narrow, it can enter [inside the skull] but it cannot come out. A patient with this condition must be trephined fully so that the ichor that may have come in may flow out. Then, medications that will absorb water will be used, and the patient will be bathed ${ }^{25}$.

Dry medications, which prevented suppuration of recent wounds, included copper oxide, lead metal, alum, chalcitis (copper sulphate) ${ }^{26}$. The bathing of the patient was prescribed possibly because it relieved "head heaviness", eased pain, and was generally helpful in many conditions ${ }^{27}$.

If the Hippocratic physician found an undisplaced fracture, he would proceed with the most dangerous of his manœuvers, trephination of the skull, in spite of the very serious danger of infection and the pain inflicted on the patient. In the same situation, on the other hand, the Egyptian physician would draw together the margins of the wound and lay fresh meat upon it without bandaging the head, probably to avoid pressure on the undisplaced fracture and the possibility of displacing the fragments; the usual application of grease and honey would follow. The Egyptian physician also 
noted that fractures of the skull were sometimes followed by rigidity of the neck (a sign of benign meningism or mortal meningitis).

The case of comminuted fracture of the skull (with possible involvement of the base, as suggested by bleeding from nose and ear) is declared by the Egyptian physician "an ailment not to be treated", in other words, a desperate case. No fresh meat and no bandage are applied (they would only have made things worse by applying pressure on the fragments and pushing them deeper into the skull), and the patient is simply put "at his mooring stakes", that is, no therapy is given.

When dealing with a displaced or comminuted fracture of the skull, the Hippocratic physician does not trephine (the ichor, presumably, can come out from the shattered skull without the need of an additional opening) nor does he try to remove the bone fragments (the attempt could cause further cerebral damage). This commendable restraint, however, is marred by the strange idea that these fractures are less dangerous than simple, undisplaced ones.

It is difficult to explain how the author of On Wounds in the Head could be so mistaken and confused concerning skull trauma, especially in view of the much more clear-headed and appropriate approach of the Egyptian physician, who was treating the same lesions more than a thousand years before. This is made more intriguing by the fact that the author of On Wounds in the Head obviously had sufficient experience to be able to make the following important observation:

If the patient has the lesion on the left side of the head, spasm sizes the right side of the body; if he has the lesion on the right side of the head, spasm sizes the left side of the body ${ }^{28}$.

It is to be noted that this concept is not clearly stated in the Smith Papyrus even if the physician may have come close to arriving at the same conclu$\operatorname{sion}^{29}$. In spite of his experience, however, the Hippocratic author insisted on a course of action that often must have been catastrophic for the patient. Perhaps we must consider this as an example of how strict adherence to a preconceived idea or theory (e.g., the percolation of ichor mentioned above) may be pernicious.

Notwithstanding the obvious difference between the Egyptian and the Hippocratic approach to skull fractures, Inversen found that "on essential points, there is an astonishing and absolute agreement between the Egyptian and the Hippocratic views on these lesions and their nature... this also applies to therapeutic measures; it seems impossible to show any difference 
in principle with regard to the actual treatment of the wounds, but in certain particular cases the Greeks employed a new surgical procedure, i. e., trephining ${ }^{30}$." It is also of interest that our enthusiasm for Hippocratic medicine is such that assertions of the superiority, even in this particular field, of the Greek surgeons vis-à-vis their Egyptian counterparts are not lacking. Even in fairly recent literature it has been maintained that a comparison of the cranial traumatology of the Smith Papyrus with the Hippocratic writings on the same subject shows that "the Greek text is infinitely superior to the Egyptian one in its technical content", and that "the Greek surgeons greatly surpass their Egyptian predecessors in theoretical knowledge as well as in know-how in traumatology ${ }^{31}$." We have seen that this may not be the case. 


\section{Endnotes}

1 Plinio Prioreschi, "Supernatural Elements in the Hippocratic Corpus", J. Hist. Med. Allied Sciences, 47, 4, 389-404, 1992.

2 Plinio Prioreschi, "Egyptian and Greek Medicine", in press.

3 Edwin Smith Surgical Papyrus in Facsimile and Hieroglyphic Transliteration with Translation and Commentary, edited by James Henry Breasted, Chicago, The University of Chicago Oriental Institute Publications, 2 vols., 1930, I, p. 9.

4 Edwin Smith Surgical Papyrus in Facsimile and Hieroglyphic Transliteration with Translation and Commentary, edited by James Henry Breasted, Chicago, The University of Chicago Oriental Institute Publications, 2 vols., 1930.

5 The Surgical Treatise is the text on the recto of the Papyrus. The text on the verso consists of incantations and recipes that have no connection with The Surgical Treatise. Usually, however, references to the Smith Papyrus are to the text on the recto, that is, to The Surgical Treatise.

6 In quotations from the Smith Papyrus, the square brackets indicate lacunae in the text filled by Breasted, the round brackets words supplied by Breasted to clarify the meaning of the text.

7 Edwin Smith Surgical Papyrus in Facsimile and Hieroglyphic Transliteration with Translation and Commentary, edited by James Henry Breasted, Chicago, The University of Chicago Oriental Institute Publications, 2 vols., 1930, I, pp. 118-124.

8 In spite of Breasted's translation of this passage, it is not clear whether Egyptians used to suture wounds. Ebbell, for example, believed that they did not. See: Plinio Prioreschi, $A$ History of Medicine, Vol.I, Primitive and Ancient Medicine, Lewiston, The Edwin Mellen Press, 1991, pp. 362-363.

9 Edwin Smith Surgical Papyrus in Facsimile and Hieroglyphic Transliteration with Translation and Commentary, edited by James Henry Breasted, Chicago, The University of Chicago Oriental Institute Publications, 2 vols., 1930, I, pp. 125-139.

10 The Smith Papyrus mentions also a "Treatise on What Pertains to a Wound", and a "Treatise on What Pertains to the Embalmer (or Bandager)". This "suggests the existence of a literature of medical science now totally lost to us". Probably "His Wound" is an error of the scribe for "A Wound". See: Edwin Smith Surgical Papyrus in Facsimile and Hieroglyphic Transliteration with Translation and Commentary, edited by James Henry Breasted, Chicago, The University of Chicago Oriental Institute Publications, 2 vols., 1930, I, p. 163.

11 In case of head wound, the Hippocratic physician, to investigate the status of the underlying skull, would begin by incising the wound to lay bare the bone, then he would continue with a series of measures that could culminate in trephining.

12 Literally, "seat" or "place", that is, an indentation on the surface of the bone.

13 On Wounds in the Head, xiv. Translation by E.T. Withington, Cambridge, Harvard University Press, the Loeb Classical Library, 1928.

14 "The salve probably was cobbler's blacking because, for the same operation, Celsus prescribes just that: atramentum sutorium. It was made with green vitriol or ferrous 
sulphate mixed with oak bark or galls. In medicine it has several uses, including the treatment of wounds. It was supposed to be caustic and hemostatic." Guido Majno, The Healing Hand: Man and Wound in the Ancient World, Cambridge, Harvard University Press, 1975, p. 493, note No 148.

15 On Wounds in the Head, xiv. Translation by E.T. Withington, Cambridge, Harvard University Press, The Loeb Classical Library, 1928.

16 Celsus, De Medicina, VIII, iii, 2.

17 Guido Majno, The Healing Hand: Man and Wound in the Ancient World, Cambridge, Harvard University Press, 1975, p. 169.

18 On Wounds in the Head, xxi. Translation by E.T. Withington, Cambridge, Harvard University Press, The Loeb Classical Library, 1928.

19 Celsus, De Medicina, VIII, iii, 8.

20 In Epidemics $V$, xvi, in fact, a case of such a complication is described although the author concludes that trephining had nothing to do with the infection.

21 On Wounds in the Head, xvii. Translation by E.T. Withington, Cambridge, Harvard University Press, The Loeb Classical Library, 1928.

22 "In omni vero fisso fractove osse protinus antiquiores medica ad ferramenta veniebant, quibus id exciderent: sed multus melius est ante emplastra experiri, quae calvaria causa componuntur" (Celsus, De Medicina, VIII, iv, 10), that is: "In all cases of fissured or fractured bone, the ancient physicians would immediately use surgical instruments to cut it. But it is much better first to try the plasters which are prepared for the cranium." Translation by P. Prioreschi.

23 On Wounds in the Head, xix. Translation by E.T. Withington, Cambridge, Harvard University Press, The Loeb Classical Library, 1928.

24 Guido Majno, The Healing Hand: Man and Wound in the Ancient World, Cambridge, Harvard University Press, 1975, p. 168.

25 On Places of Man, xxxii, Littré, VI, p. 324. Translation by P. Prioreschi.

26 On Wounds, xiii, Littré, VI, p.416.

27 Regimen in Acute Diseases, xviii, Littré, II, pp.364-376.

28 On Wounds in the Head, xix. Translation by E.T. Withington, Cambridge, Harvard University Press, The Loeb Classical Library, 1928.

29 Edwin Smith Surgical Papyrus in Facsimile and Hieroglyphic Transliteration with Translation and Commentary, edited by James Henry Breasted, Chicago, The University of Chicago Oriental Institute Publications, 2 vols., 1930, I, p. 66. It has been stated that "according to the Egyptian text, the paralysis of the limbs is on the same side as the cranial lesion (Smith Papyrus, 9) whereas the Hippocratic physicians knew very well that, in such cases, the hemiplegia is controlateral" (Mirko Drazen Grmek, "Anciennete de la chirurgie hippocratique", in Formes de pensée dans la collection hippocratique, Actes du IVe Colloque International Hippocratique, edited by F. Lasserre and P. Mudry, Genève, Librairie Droz, 1983, pp. 285-295). The fact is that in case 8 (not 9 as Grmek says) of the Smith papyrus, is mentioned a fracture of the skull with paralysis on the same side but, as the immediate damage to the brain was minor (the patient was walking), it could have been a case of contre-coup. In addition, the Egyptian text describes an individual case without generalization and, although it may not have been known when the Smith papyrus was written that the paralysis is controlateral to the brain lesion, case 8 does not prove it. 
30 Erik Inversen, "Wounds in the Head in Egyptian and Hippocratic Medicine", Studia orientalia Ioannis Pedersen dedicata, Copenhagen, Munksgaard, 1953, pp.163-171.

31 "Par son contenu technique, le texte grec est infiniment supérieur au texte égyptien", and "les chirurgiens grecs surpassent de beaucoup, aussi bien en connaissances théoriques sûres qu'en savoir-faire traumatologique, leurs prédécesseurs égyptiens." Mirko Drazen Grmek, "Ancienneté de la chirurgie hippocratique", in Formes de pensée dans la collection hippocratique, Actes du IVe Colloque International Hippocratique, Lausanne, 21-26 September, 1981.

Prof. Plinio Prioreschi, M. D.

Creighton University, School of Medicine

Dept. of Pharmacology, Division of History of Medicine

California at 24th Street

USA-Omaha Nebraska 68178 